\title{
Ultrastructural Study of the Denervated Diaphragm in Rats
}

\author{
Estudio Ultraestructural del Diafragma Desnervado en Ratas
}

\author{
Torrejais, M. M.*; Soares, J. C. **; Matheus, S. M. M.**; Mello, J. M.*** \\ Francia-Farje, L. A. D. ${ }^{* * * * *} ;$ Jeronimo, L. C. ${ }^{* * * * * *}$ \& Vicente, E. J. D. ${ }^{* * * * * * *}$
}

\begin{abstract}
TORREJAIS, M. M.; SOARES, J. C.; MATHEUS, S. M. M.; MELLO, J. M.; FRANCIA-FARJE, L. A. D.; JERONIMO, L. C. \& VICENTE, E. J. D. Ultrastructural study of the denervated diaphragm in rats. Int. J. Morphol., 31(3):925-931, 2013.
\end{abstract}

SUMMARY: The structural alterations that occur in the muscle fibers of denervated rat diaphragms were studied. Fifteen adult male albino rats (Rattus norvegicus) with a mean weight of $200 \mathrm{~g}$ and about 60 days of age were used. Chronically denervated diaphragms were obtained and the animals were sacrificed after 4,8 and 12 weeks of denervation. The left antimere of the diaphragm was denervated by sectioning of the phrenic nerve and the right antimere served as control. Each antimere was divided into fragments, which were used for analysis transmission electron microscopy. During the initial phase of denervation (4 weeks), ultrastructural muscle modifications appeared in scattered fibers and in foci along these fibers. Muscle fibers with foci of less dense and loosely arranged myofibrils, disor ganized Z line, displaced T tubules, and central nucleus exhibiting reentrances and fragmented aspect were observed. After 8 weeks, formation of large aggregates of small elongated mitochondria showing altered cristae, matrix inclusions and increased electron density was noted. At 12 weeks of denervation the alterations were found to be more drastic. Nuclei with internal deposits of myofibrillar or amorphous material were observed. In these fibers, vacuoles harbored enormous myeloid structures in the subsarcolemmal or intermyofibrillar region.

KEY WORDS: Denervation; Diaphragm; Muscle fiber; Ultrastructural; Rat.

\section{INTRODUCTION}

According to Fennekens (1992), atrophy is due to a reduction in the contractile material which seems to be related to an increase in protein degradation and a decrease in protein synthesis. During this phase, atrophic fibers are characterized by the presence of lysosomes and increased endocytic activity. Other ultrastructural aspects include an irregular and folded sarcolemma, thinner and more disorganized myofibrils, enlarged sarcoplasmic reticulum, mitochondria showing increased volume and reduction in the number of cristae which are frequently transformed into "myelin figures", a more prominent $\mathrm{T}$ tubule arranged longitudinally in relation to the myofibrils, autophagous vacuoles, and lipofuscin residues derived from lysosomal action (Cullen et al., 1992).

In addition to the alterations described, a variable proportion of muscle fibers enter an irreversible process of degeneration after long periods without innervation (McComas, 1977; Anzil \& Wernig, 1989). The affected muscle cells become swollen and, together with their nuclei, start to fragment. Vacuoles appear in the cytoplasm, basophilia increases, and the striations become less distinct before the fibers disintegrate. Phagocytic cells accumulate at the sites of necrosis which participate in the process of removal of muscle fiber remnants. Complete destruction of a muscle fiber may finally occur (McComas), but there is no doubt that some muscle fibers conserve their characteristic striations even when denervation continues for a long period of time (Anzil \& Wernig).

In addition, so-called "target fibers" are observed at a lower frequency during the processes of denervation as well as reinnervation, and are characterized by the presence of a generally central region and the absence of activity of oxidative metabolism enzymes (Engel, 1961; Fennekens; Louglin, 1993). Ultrastructural analysis of the target region reveals the presence of amorphous material containing disintegrated myofilaments, abnormal mitochondria and

\footnotetext{
Medical and Pharmaceutic Sciences Center, UNIOESTE, Cascavel, Paraná, Brazil.

** Department of Anatomy - Biosciences Institute, UNESP, Botucatu, São Paulo, Brazil.

**** Department of Morphologic Sciences, UEM, Maringá, Paraná, Brazil.

***** Integrated Faculty of Bauru, FIB, Bauru, São Paulo, Brazil.

******* Master of Bioscience and Health, UNIOESTE, Cascavel, Paraná, Brazil.

******* Department of Physiotherapy, UFJF, Juiz de Fora, Minas Gerais, Brazil.
} 
multivesicular bodies. Most authors report that target fibers are more frequently found in type I fibers. However, Jaweed et al. (1975), studying rats submitted to denervation, observed the presence of this phenomenon only in type II fibers.

Satellite cells and other cell types are identified between muscle fibers after denervation (McGeachie \& Allbrook, 1978; Murray \& Robbins, 1982; McGeachie, 1989). A large number of fibroblasts appears in the endomysial and perimysial spaces, followed by macrophages. The number of Schwann cells is also increased during the processes of neuromuscular degeneration and regeneration.

Particularly with respect to human skeletal muscles, determination of the effects of muscle fiber denervation becomes difficult because in most neurogenic disorders denervated and reinnervated fibers are present side by side in samples removed for diagnosis. Highly atrophic fibers might safely be considered denervated, whereas less atrophic fibers may represent both fibers in the process of atrophy and those in the process of reinnervation and recovery. On the other hand, atrophy due to denervation can be sequentially analyzed in completely denervated muscles of animals (Engel \& Banker, 1994).

Representing a striated skeletal muscle with special functional characteristics considering its uninterrupted activity throughout the life of a healthy individual, the diaphragm is an attractive model for the study of events associated with the process of denervation. Another relevant aspect is that the normal hemidiaphragm, in addition to satisfactorily maintaining the respiratory conditions of the animals, serves as a control for morphological or functional evaluation.

\section{MATERIAL AND METHOD}

All experimental procedures were conducted in accordance with the Ethical Principles of Animal Experimentation adopted by the Brazilian College of Animal Experimentation (COBEA) and the study was approved by the Ethic Committee on Animal Experimentation (CEEA - IBUNESP) on June 2, 1999.

Fifteen adult male albino rats (Rattus norvegicus) with a mean weight of $200 \mathrm{~g}$ and about 60 days of age, obtained from the Central Animal House, UNESP, Botucatu Campus, SP, Brazil, were used. The animals were anesthetized with intraperitoneal injections of $3 \%$ sodium pentobarbital $(1.0 \mathrm{mg} /$ $\mathrm{kg}$ ). Preparations of chronically denervated diaphragm were obtained according to the method of Vital-Brazil (1965) described for rats.
Five animals from each group were sacrificed 4, 8 and 12 weeks after denervation. The left antimere of the diaphragm was used as the experimental specimen and the right antimere served as control. Each hemidiaphragm was divided into fragments, which were used for muscle fiber analysis by TEM.

The muscles were removed and cut into approximately 1-mm long longitudinal fragments. The specimens were immersed in $2.5 \%$ glutaraldehyde in $0.1 \mathrm{M} \mathrm{PBS}, \mathrm{pH} 7.2$, and submitted to routine processing for TEM. The material was examined and photographed under a Philips CM-100 transmission electron microscope.

\section{RESULTS}

A. Control group. In the hemidiaphragms used as controls, two frequent types of muscle fibers could be identified. One type was characterized by a compact myofibrillar arrangement, a dense and wide $\mathrm{Z}$ line and clearly visible $\mathrm{M}$ line and $\mathrm{A}, \mathrm{I}$ and $\mathrm{H}$ bands. Large mitochondria forming intermyofibrillar chains were frequent in sarcomeres and in subsarcolemmal aggregates as well. The triads were clearly visible in some sarcomeres (Fig. 1A). These morphological characteristics are compatible to those described for type I fibers by histological analysis, i.e., they show an oxidative metabolism, are resistant to fatigue and contract more slowly.

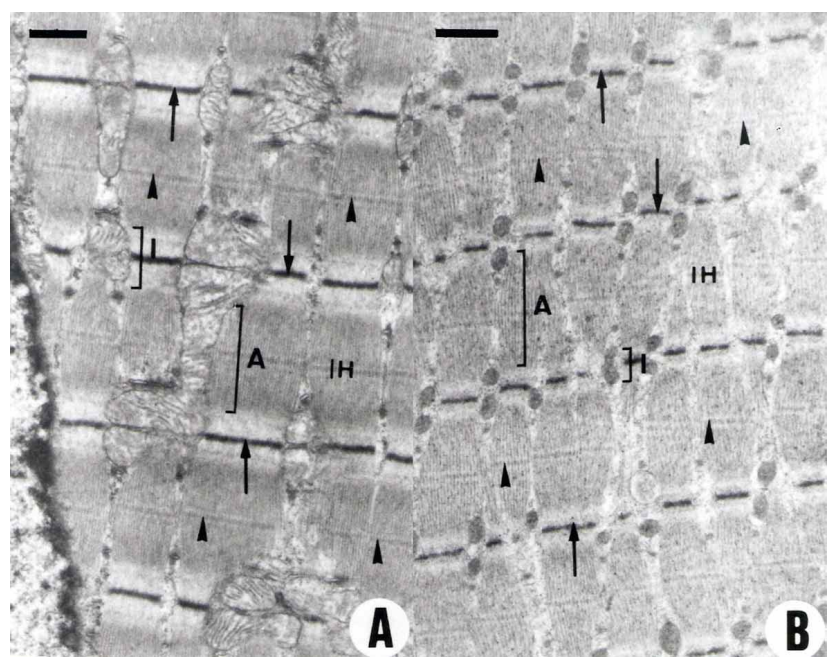

Fig. 1. Transmission electron photomicrographs of longitudinal sections of the diaphragm of a control rat. A: Type I muscle fiber: thick $\mathrm{Z}$ line (arrows); $\mathrm{M}$ line (arrowheads); A (A), I (I) and $\mathrm{H}(\mathrm{H})$ bands; mitochondria forming chains. $\mathrm{Bar}=0.75 \mu \mathrm{m}$. B: Type II muscle fibers: thin $\mathrm{Z}$ line (arrows); mitochondria on both sides of the Z line; A (A), I (I) and $\mathrm{H}(\mathrm{H})$ bands; $\mathrm{M}$ line (arrowheads). Bar $=0.93 \mu \mathrm{m}$.

$\mathrm{D}$ and E: Nuclei showing reentrances and a fragmented aspect. Bars $=1.02 \mu \mathrm{m}$ and $1.29 \mu \mathrm{m}$, respectively. 


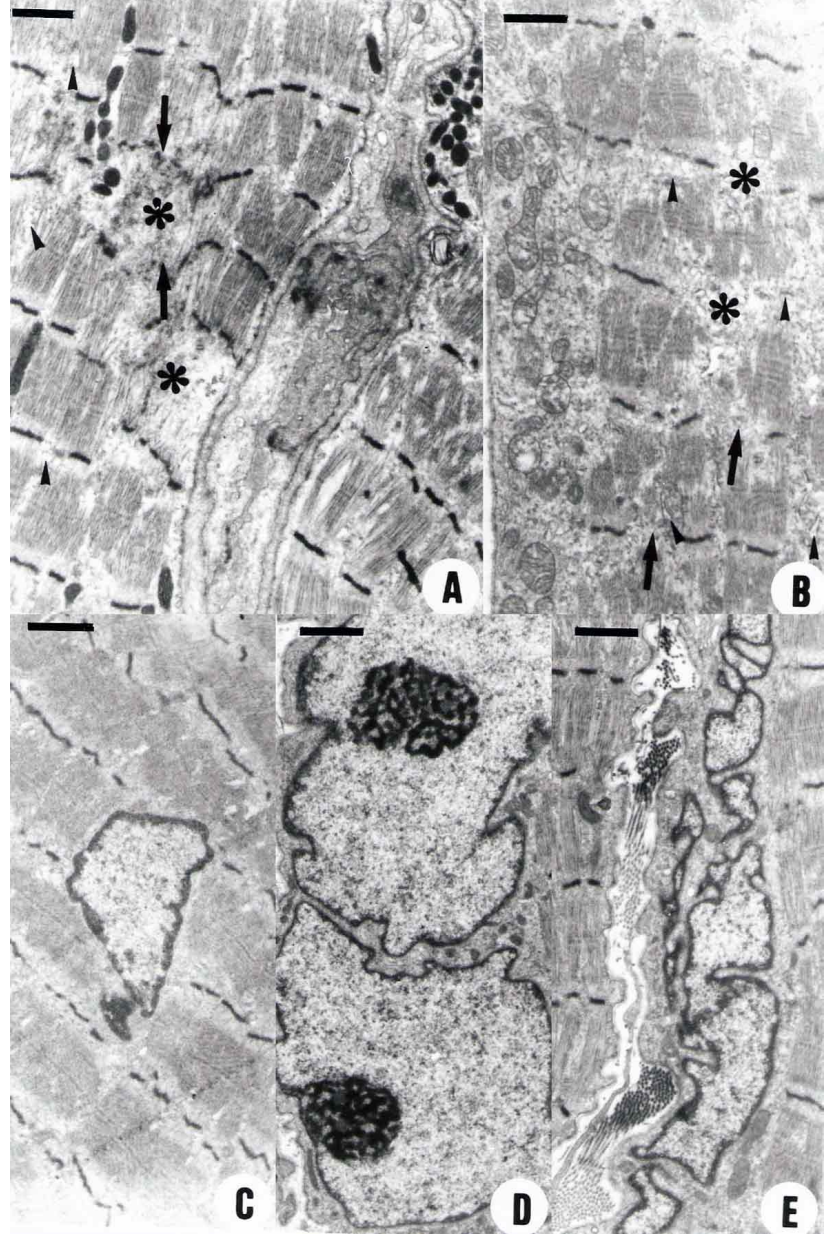

Fig. 2. Transmission electron photomicrographs of longitudinal sections of the rat diaphragm 4 weeks after denervation. A and B: Muscle fibers showing foci of less dense or loosely arranged myofibrils (black asterisk), disorganized $\mathrm{Z}$ line (arrows) and displaced T tubules (arrowheads). Bars $=1.02 \mu \mathrm{m}$ and $0.59 \mu \mathrm{m}$, respectively. C: Central nucleus in the muscle fiber. Note the absence of mitochondria. $\mathrm{Bar}=1.02 \mu \mathrm{m}$.

The other muscle fiber type also presented distinct sarcolemmal lines and bands, but the $\mathrm{Z}$ line was thinner. The mitochondria, which were always arranged in pairs on each side of the $\mathrm{Z}$ line in the I band, were smaller and did not form aggregates or columns. The myofibrillar arrangement was looser and glycogen was observed between myofibrils at higher magnifications, as well as triads at the height of the $\mathrm{Z}$ line (Fig. 1B). This morphological profile is characteristic of fibers described as type II by histological analysis, which present a glycolytic metabolism, are poorly resistant to fatigue and show rapid contraction.

B. Denervated group after 4 weeks. TEM analysis of the denervated hemidiaphragms demonstrated a growing set of morphological alterations according to the temporal evolution of denervation. Although light microscopic structural lesions were highly discrete, important modifications in fibrillar ultrastructure were already observed during the first weeks after neurotomy in foci along some scattered fibers. The foci into this muscle fibers represent regions where less dense or loosely arranged myofibrils were present. In addition, alterations in sarcomere banding as well as in the position and shape of the T tubules and in sarcoplasmic reticulum cisternae were observed (Figs. 2A and 2B). Central nuclei in the muscle fiber were already frequent during this phase (Fig. 2C). The nuclei presented a highly sinuous profile characterized by reentrances which sometimes suggested fragmentation (Figs. 2D and 2E). Four weeks after denervation, dissolution of the $\mathrm{Z}$ line was observed in various regions, normally accompanied by a decrease in the number of mitochondria present in the I band and associated with focal degeneration of myofibrils (Figs. 2A and 2B). The remaining mitochondria were dilated and sarcoplasmic reticulum elements were found to be

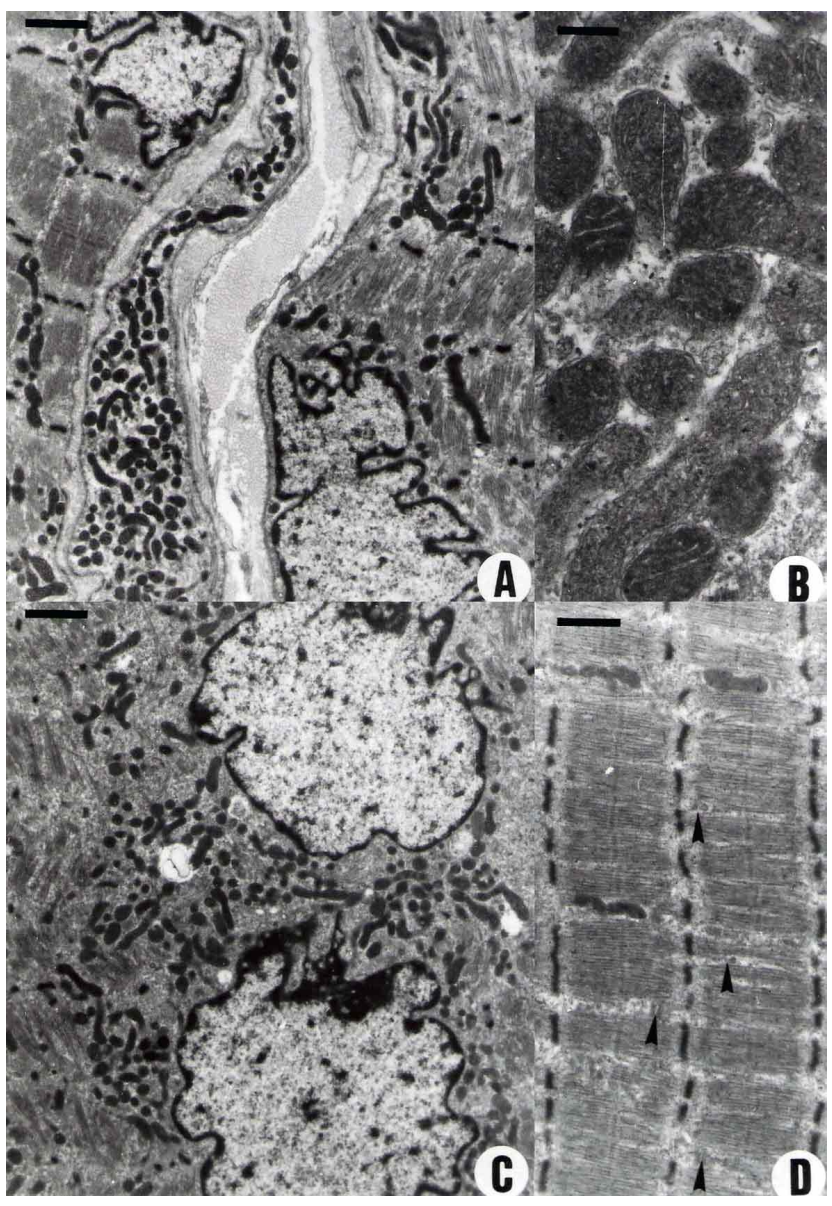

Fig. 3. Transmission electron photomicrographs of longitudinal sections of the rat diaphragm 8 weeks after denervation. A, B and C: Mitochondrial aggregates in an intermyofibrillar or juxtanuclear position. Note the elongated mitochondria showing altered cristae, matrix inclusions and increased electron density. Bars $=1.02 \mu \mathrm{m}$, $0.28 \mu \mathrm{m}$, and $1.29 \mu \mathrm{m}$, respectively. D: Displaced sarcoplasmic reticulum cisternae and T tubules (arrowheads). Bar $=0.75 \mu \mathrm{m}$. 
displaced and reduced in number. Other fibers of normal appearance were observed in neighboring regions. Satellite cells sharing the basal lamina of the adjacent muscle fiber were noted but did not show signs of increased biological activity.

C. Denervated group after 8 weeks. A relevant aspect observed in denervated muscle fibers after 8 weeks was the formation of large mitochondrial aggregates concentrated in juxtanuclear or intermyofibrillar position. These organelles were elongated and presented altered cristae, in addition to dense matrix inclusions (Figs. 3A, 3B and 3C). At lower magnifications it was observed a marked reduction in muscle fiber dimensions. Cell infiltrates and highly dense collagen fiber bundles filled the interstitial spaces replacing degenerated fibers (Figs. 4A and 4B).

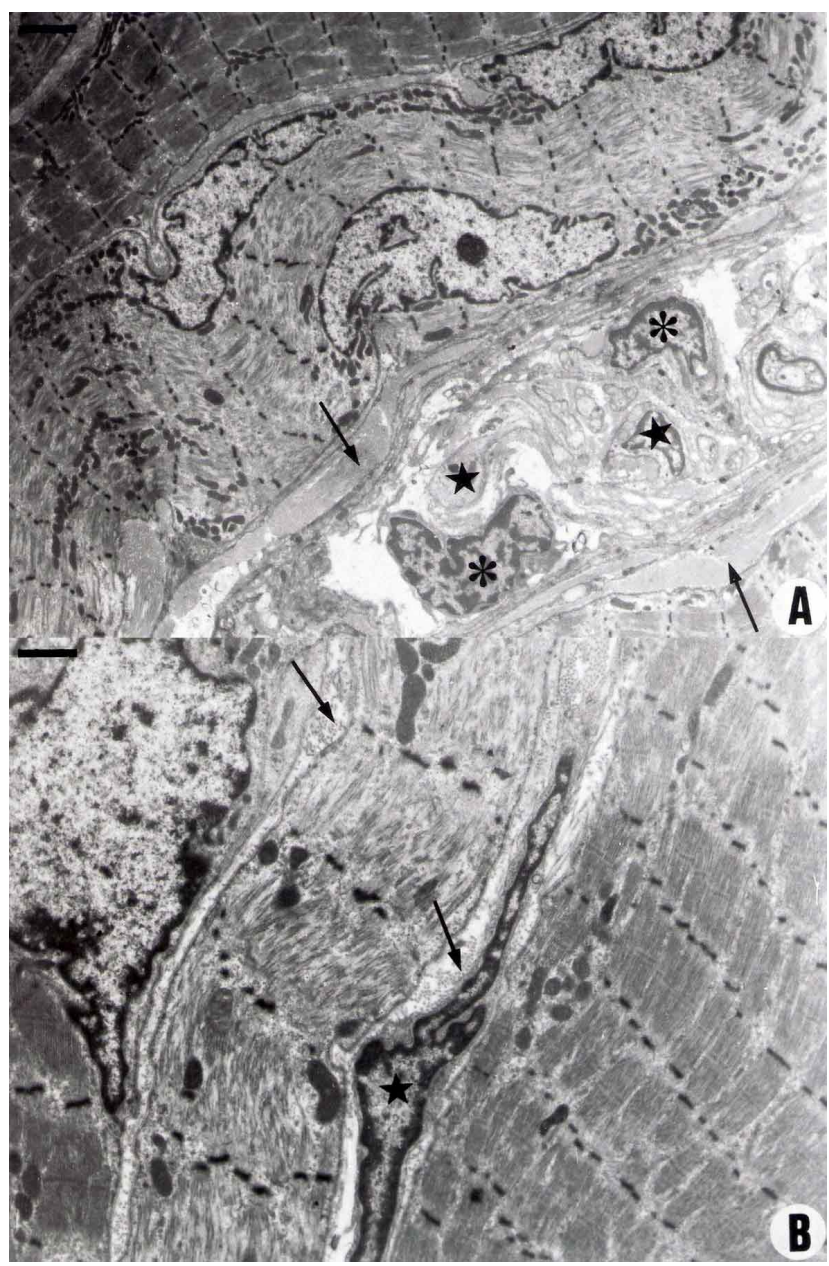

Fig. 4. Transmission electron photomicrographs of longitudinal sections of the rat diaphragm 8 weeks after denervation. A and B: Reduction in muscle fiber dimensions; cell infiltration of degenerated muscle fibers that maintain their membrane integrity. Note macrophages (black asterisk) among other cells (black star), basal lamina exuberance, and collagen fibers (arrows) replacing degenerated fibers. Compare the different degrees of injury in neighboring fibers. Bars $=2.3 \mu \mathrm{m}$ and $1.02 \mu \mathrm{m}$, respectively.
D. Denervated group after 12 weeks. After more prolonged periods of denervation (12 weeks) the alterations were found to be cumulative and more drastic (Fig. 5). During this phase, in addition to much more frequent central and very irregular nuclei, intranuclear inclusions corresponding to cytoplasmic portions of fibrillar or amorphous material were observed (Fig. 5A). In these fibers, vacuoles harbored enormous myeloid structures in the subsarcolemmal or even in the intramyofibrillar region (Figs. 5C and 5D). During this phase of denervation, most muscle fibers were characterized by structural alterations, although some still kept a certain degree of organization. Even in more preserved muscle fiber regions, displacement of the triads and dilatation of sarcoplasmic reticulum cisternae were noted (Fig. 5B).

\section{DISCUSSION}

Denervation of the diaphragm was successful as demonstrated by macroscopic observations of specimens removed en bloc and examined by transillumination. The procedure proposed by Vital-Brazil (1965) was found to be simple and fast and showed a high success rate indicated by low morbidity considering the extent and location of the surgical lesions.

Ultrastructural analysis provides information regarding the mechanisms of a cellular pathology and suggests etiological factors of neuromuscular disorders. The $\mathrm{Z}$ disc plays an important role in the maintenance of the structural integrity of myofibrils. Dissolution of the $\mathrm{Z}$ disc is common in atrophies resulting from denervation and starts with focal myofibrillar degeneration (Engel, 1967). According to this author, structural alterations in the $\mathrm{Z}$ disc are commonly associated with a decrease in the number of mitochondria. In tenotomized animals, disintegration of the $\mathrm{Z}$ disc in areas where mitochondrial reduction occurs is more commonly observed in type I than in type II fibers, suggesting that the integrity of this structure is more dependent on the mitochondria of type I fibers (Shafiq et al., 1969). One may speculate that the reduction in the number of mitochondria, or some factor that impairs the uptake of calcium by this organelle, may result in high intermyofibrillar calcium concentrations when this ion is released from the sarcoplasmic reticulum. This change might cause more marked damage to type I fibers since the calcium pump is less effective in this type of fiber. These metabolic modifications may alter calcium homeostasis and induce focal myofibrillar degeneration initiating from the $\mathrm{Z}$ disc (Carafoli, 1982). The present histoenzymological observations suggest that type II fibers are more susceptible to the damage caused by denervation, at least during the initial phases of this process. 

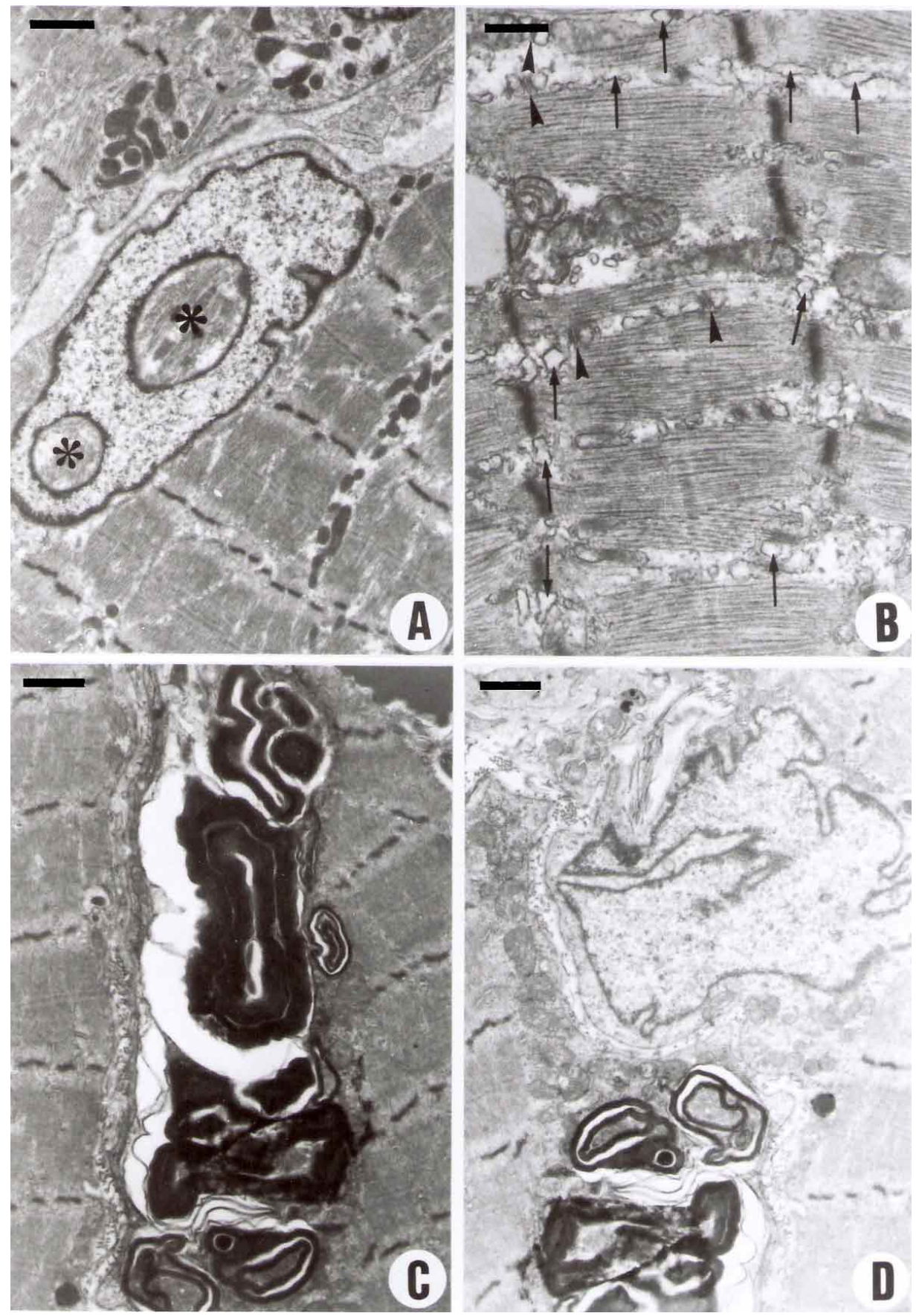

Figure 5. Transmission electron photomicrographs of longitudinal sections of the rat diaphragm 12 weeks after denervation. A: Nucleus with an internal deposit of myofibrillar material (black asterisk). Bar $=1.02 \mu \mathrm{m}$. B: Displacement of the triads (arrowheads) and dilated sarcoplasmic reticulum cisternae (arrows). Bar $=0.32 \mu \mathrm{m}$. C and D: Vacuoles harboring enormous myeloid structures in the subsarcolemmal or intramyofibrillar region. Bar $=5.13 \mu \mathrm{m}$.

Ultrastructural analysis, however, indicated that type II fibers seem to be less damaged than type I fibers along the different study times. The precise characterization of the diaphragm fiber types, especially after longer periods of denervation, was impaired by the profound alterations in myofibrillar, mitochondrial and $\mathrm{Z}$ disc organization.
The apparent increase in mitochondrial size observed in the longitudinal sections of some fibers obtained from recently denervated muscles might have been due to spatial reorientation of these organelles. In contrast, small mitochondrial aggregates may form between aberrant myofibril bundles and are usually associated with glycogen granules in various myopathies (Tice \& Engel, 1967). This aspect was observed in the present study 8 weeks after denervation, in addition to changes in the cristae orientation and the presence of mitochondrial matrix inclusions. Crystalloid inclusions may indicate disturbances in mitochondrial function, such as uncoupling agents (Eppenberger-Eberhardt et al., 1991) or temporary ischemia (Mukherjee et al., 1986). Other types of inclusions have been described in the literature, as well as more detailed aspects of the mitochondrial ultrastructure in different diseases. A detailed assessment of these aspects was not the main concern of the present investigation but may provide perspectives for further morphological studies aimed at a better characterization and explanation of these phenomena.

During the final period of denervation, ultrastructural analysis revealed the presence of large myeloid structures in the atrophic muscle fibers. These myeloid structures, which varied in size and electron density, differed from the autophagous vacuoles described in various others myopathies since they were not 
surrounded by a discontinuous membrane. In addition, they contained membranous structures presenting different degrees of degradation. According to Nonaka et al. (1981), these myeloid structures suggest that lysosomal or extra-lysosomal organelle destruction may occur in some myopathies in which the ability of fibers to sequestrate, degrade and eliminate degradation products is affected.

The $T$ tubule system is an internal expansion of the sarcoplasmic membrane and plays an important role in the transmission of electrical impulses to the interior of the muscle fiber. In the present study, another structural aspect observed in atrophic fibers since the early periods of denervation, which became more marked with time, was the displacement and dilatation of $\mathrm{T}$ tubules and sarcoplasmic reticulum cisternae. According to Santa \& Engel (1974), this displacement is particularly evident in areas of marked myofibrillar degeneration and is always associated with displacement of sarcoplasmic reticulum elements. At more advanced stages of denervation, these elements become more dilated in such a way that eventually impairs their recognition. According to Engel (1970), the observation of dense and irregular osmiophilic lamellae forming small myeloid structures may correspond to alterations of these structures observed in periodic paralysis or other diseases. This author described the proliferation of $\mathrm{T}$ system elements in denervated rat muscles. This finding was later confirmed for a series of pathologies and was observed here in atrophic muscle fibers 12 weeks after denervation.

Invasion and destruction of non-necrotic muscle fibers by mononuclear cells is frequently observed in polymyositis and myositis, is rare in dermatomyositis and scleroderma, and occasionally occurs in genetic myopathies such as Duchenne's muscular dystrophy (Engel \& Banker). T lymphocytes and macrophages invade non-necrotic muscle fibers through a mechanism that is still not completely understood and this invasion seems to be cell mediated since some characteristic events occur: a) no zeiosis is observed - a phenomenon in which the organelles and sarcolemma of the target cell remain intact for a period ranging from a few minutes to some hours, followed by violent deterioration of the cell membrane and disintegration of the cell; b) the muscle fiber is physically replaced with invading cells; c) the invaded fibers probably survive for some additional hours, or for a period sufficient to show changes suggestive of regeneration, and d) both $\mathrm{T}$ lymphocytes and macrophages participate in the cell-mediated destruction of the muscle fiber. This entire process has been reported for diseases with inflammatory and autoimmune characteristics. However, a similar profile of muscle fibers containing macrophages is observed in degenerating atrophic fibers resulting from denervation as demonstrated throughout the present study, but this aspect has not been emphasized in the literature.
The most common changes related to myonuclei in pathological processes involving muscle fibers include central migration, deep nuclear membrane folds, degeneration, and nuclear inclusions, in addition to other abnormalities. Migration of the nucleus to the center of the muscle fiber is a common event in all muscle disorders and also occurs during atrophy due to denervation as observed throughout the present study. Nuclear membrane folds may incompletely divide the nucleus and invaginations can cover part of the surrounding cytoplasm where myofibrils appear inside the nucleus. According to Banker (1967), these neighboring structures are internalized and initially remain covered by a double membrane. During a later phase, the content of these inclusions is transformed into electron-dense and homogenous material. These densely grouped filaments are only occasionally visible in myonuclei. The chromatin condensation and marginalization and the presence of nucleoli observed on many occasions in the denervated animals has been mentioned in the literature only for polymyositis, dermatomyositis and mitochondrial myopathy (Banker, 1975).

\section{CONCLUSIONS}

Analysis of the present results and comparison with data reported in the literature permit us to conclude that after denervation of the rat diaphragm a) muscle fibers respond differently to the process of denervation, with some fibers showing focal lesions and disorganization of fibrillar elements and organelles earlier than others; b) muscle fibers in an advanced stage of degeneration present an intact muscle membrane, suggesting that they support a temporal interstitium until their complete destruction.

ACKNOWLEDGEMENTS. The authors thank CNPq for support, proc. 141.412/98-4

TORREJAIS, M. M.; SOARES, J. C.; MATHEUS, S. M. M.; MELLO, J. M.; FRANCIA-FARJE, L. A. D.; JERONIMO, L. C. \& VICENTE, E. J. D. Estudio ultraestructural del diafragma desnervado en ratas. Int. J. Morphol., 31(3):925-931, 2013.

RESUMEN: Fueron estudiadas las alteraciones ultra estructurales de las fibras musculares del diafragma denervado de ratas. Fueron utilizadas 15 ratas albinas (Rattus norvegicus), machos, adultas, con peso promedio de $200 \mathrm{~g}$ de aproximadamente 60 días de edad. Los diafragmas crónicamente denervados fueron obtenidos después de 4, 8 y 12 semanas de denervación. El antímero izquierdo del diafragma fue denervado por sección del nervio frénico y el antímero derecho fue utilizado como control. Cada antímero fue dividido en fragmentos, que fueron utilizados para el estudio en microscopia electrónica de transmisión. Durante los períodos iniciales de denervación (4 semanas), las modificaciones en la ultraestructura del músculo se 
disponen en fibras dispersas y en focos a lo largo de las mismas. Se observan fibras musculares con focos de miofibrillas rarefactas y laxamente dispuestas; línea $\mathrm{Z}$ desorganizada; túbulos $\mathrm{T}$ dislocados; núcleo central con aspecto fragmentado. Después de 8 semanas de denervación, se observa la formación de numeroso agregados de pequeñas mitocondrias alargadas, con alteraciones en las crestas, inclusiones en la matriz y aumento de la electrodensidad. Con 12 semanas de denervación, las alteraciones se muestran más drásticas; se observan núcleos con depósitos internos de material miofibrillar o amorfo. En estas fibras, las vacuolas presentan grandes estructuras mieloides en la región subsarcolemal o intermiofibrillar.

PALABRAS CLAVE: Denervación; Diafragma; Fibra muscular; Ultraestructura; Rata.

\section{REFERENCES}

Anzil, A. P. \& Wernig, A. Muscle fibre loss and reinnervation after long-term denervation. J. Neurocytol., 18(6):833-45, 1989.

Banker, B. Q. A phase and electron microscopic study of dystrophic muscle: I the pathological changes in the two-week-old Bar Harbor 129 dystrophic mouse. J. Neuropathol. Exp. Neurol., 26(2):259-75, 1967.

Banker, B. Q. Dermatomyositis of childhood. Ultrastructural alterations of muscle and intramuscular blood vessels. $J$. Neuropathol. Exp. Neurol., 34(1):46-75, 1975.

Carafoli, E. The regulation of intracellular calcium. Adv. Exp. Med. Biol., 151:461-72, 1982.

Cullen, M. J.; Fohnson, M. A. \& Mastaglia, F. L. Pathological reactions of skeletal muscle. In: Mastaglia, F. L. \& Walton, J. N. (Eds.). Skeletal muscle pathology. Edinburgh, Churchill Livingstone, 1992. pp.123-84.

Engel, W. K. Muscle target fibres, a newly recognized sign of denervation. Nature, 191:389-90, 1961.

Engel, A. G. Pathological reactions of the Z disk. Excerpta Medica ICS, 147:398-411, 1967.

Engel, A. G. Evolution and content of vacuoles in primary hypokalemic periodic paralysis. Mayo Clin. Proc., 45(11):774814, 1970.

Engel, A. G. \& Banker, B. Q. Ultrastructural changes in diseased muscle. In: Engel, A.G. \& Frazini-Armstrong, C. (Eds.). Myology: basic and clinical. $2^{\text {nd }}$ ed. New York, Edition International, 1994. pp.889-1017.

Eppenberger-Eberhardt, M.; Riesinger, I.; Messerli, M.; Schwarb, P.; Müller, M.; Eppenberger, H. M. \& Wallimann, T. Adult rat cardiomyocytes cultured in creatine-deficient medium display large mitochondria with paracrystalline inclusions, enriched for creatine kinase. J. Cell. Biol., 113(2):289-302, 1991.
Fennekens, F. G. I. Neurogenic disordens of muscle. In: Mastaglia, F.L. \& Walton, J. N. (Eds.). Skeletal muscle pathology. 2nd ed. Edinburgh, Churchill Livingstone, 1992. pp.563-97.

Jaweed, M. M.; Herbison, G. J. \& Ditunno, J. F. Denervation and reinnervation of fast and slow muscles. A histochemical study in rat. J. Histochem. Cytochem., 23(11):808-27, 1975.

Louglin, M. Muscle biopsy: a laboratory investigation. London, Butterworth-Heinemann, 1993, p.242.

McComas, A. J. Neuromuscular junction and disorders. London, Butterworth, 1977. p.364.

McGeachie, J. K. Sustained cell proliferation in denervated skeletal muscle of mice. Cell Tissue Res., 257(2):455-7, 1989.

McGeachie, J. K. \& Allbrook, D. Cell proliferation in skeletal muscle following denervation or tenotomy. Cell Tissue Res., 193(2):25967, 1978.

Mukherjee, T. M.; Dixon, B. R.; Blumbergs, P. C.; Swift, J. G. \& Hallpike, J. F. The fine structure of the intramitochondrial crystalloids in mitochondrial myopathy. J. Submicros. Cytol., 18(3):595-604, 1986.

Murray, M. A. \& Robbins, N. Cell proliferation in denervated muscle: identity and origin of dividing cells. Neuroscience, 7(7):182333, 1982.

Nonaka, I.; Sunohara, N.; Ishiura, S. \& Satoyoshi, E. Familial distal myopathy with rimmed vacuoles and lamellar (myeloid) body formation. J. Neurol. Sci., 51(1):141-55, 1981.

Santa, T. \& Engel, A. G. Histochemical, electron microscopic and electron histochemical studies of vacuoles and tubular structures in periodic paralysis. Clin. Neurol., 14(10):792-8, 1974.

Shafiq, S. A.; Gorycki, M. A.; Asiedu, S. A. \& Milhorat, A. T. Tenotomy: effect on the fine structure of the soleus muscle of the rat. Arch. Neurol., 20(6):625-33, 1969.

Tice, L. W. \& Engel, A. G. The effects of glucocorticoids on red and white muscles in the rat. Am. J. Pathol., 50(2):311-33, 1967.

Vital-Brazil, O. Ação neuromuscular da peçonha micrurus. Hospital, 68:909-50, 1965.

\section{Correspondence to:}

Prof. Dr. Marcia Miranda Torrejais

Medical and Pharmaceutic Sciences Center

University of the State of Paraná

UNIOESTE - 85814-110

Cascavel-Paraná

BRAZIL

Received: 29-11-2012

Accepted: 03-04-2013

Email: mmtorrejais@yahoo.com.br 